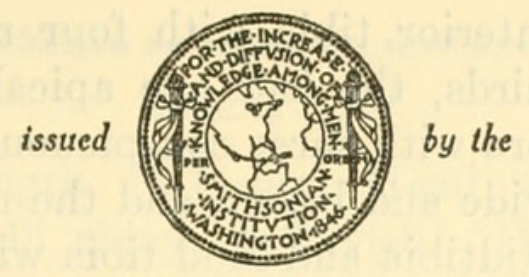

SMITHSONIAN INSTITUTION

U. S. NATIONAL MUSEUM

\title{
FOUR NEW VENEZUELAN REDUVIID BUGS
}

\section{By J. Maldonado Capriles ${ }^{1}$}

The four species described in this paper were collected by the author in different places in Territorio Amazonas, Venezuela, during an expedition sponsored by the University of Puerto Rico.

The author is greatly indebted to Dr. Petr Wygodzinsky, of the Instituto de Medicina Regional at Tucumán, Argentina, for his invaluable suggestions, and to Dr. Carl J. Drake for the loan of a paratype of Sirthenea peruviana Drake and Harris.

\section{Diarthrotarsus marahuacensis, new species}

Figure $79, a-c$

Female: Over-all length $12.2 \mathrm{~mm}$. Head grayish stramineous, lighter from between the antenna up to and including the interocular depression. Eyes brownish. First antennal segment stramineous, with reddish basal, median, and apical bands, the last darker; second yellowish, with black apical band; third with basal third stramineous, apical two-thirds reddish; fourth missing. Thorax dorsally and scutellum stramineous. Clavus and corium stramineous with a reddish tinge, veins and many small irregular markings lighter, apical angles brownish. Membrane finely corrugate, light brown, veins concolorous. Rostrum with first and second segments stramineous with narrow reddish band near apices; third segment brownish. Anterior femur, posteriorly, from base, with four alternating light and dark brown bands, each about one-fourth the length of the femur; anteriorly the two dark bands coalesce irregularly, forming an incomplete lighter

' College of Agriculture and Mechanic Arts, Mayagüez, Puerto Rico.

$319187-55$ 
band in between. Anterior tibia with four narrow reddish bands, three on basal two-thirds, the last one apical. Tarsi stramineous. Median and hind femora with three conspicuous bands on apical twothirds, the outer two wide and brown and the median narrow, incomplete, and reddish. Midtibia and hind tibia with four reddish bands; the last narrower. Midtarsi and hind tarsi reddish. Thorax laterally brownish;prosternum and metasternum stramineous, mesosternum reddish. Abdomen ventrally light brown and with many irregular dark brown and blackish spots laterally on first five segments; last two segments brown. Connexivium dorsally and ventrally with anterior halves dark brown and posterior halves reddish brown.

Head as in figure $79, a, b$. Finely granulated, with inconspicuous pilosity; slightly shorter than thorax and less than twice the width of the head across the eyes. Width of eyes dorsally less than half interocular space. Deep interocular depression. Ocelli closer to eyes than to each other. Spines behind antenniferous tubercles relatively short, from above equal to width of eye. No tubercle present behind ocelli. Antenna inconspicuously pilose; length of segments 73:50:52:- ; first segment thicker than second and third. Rostrum relatively thick; segments 32:20:14. Pronotum finely granulated; carinae granulated and more conspicuous on anterior lobe and extending to anterior part of posterior lobe. Collar with lateral angles not prominent, rounded. Spines on humeral angles broad, shorter than spines on bases of antenna, granulated. Posterior margin of pronotum slightly concave; sublateral angles roundly angulate. Scutellum carinate, ending in a horizontal process. Fore femur covered dorsally with coarse tubercles, irregularly distributed; ventrally smooth, with but a few very small tubercles; anterior margin with many setigerous spines in an even row. Hind femur and midfemur slightly incrassate at apex, with a few, scattered, very small tubercles. Upper margins of abdomen straight, margin of connexivium without elevations. Genitalia from the side as in figure 79,c. Posterior margin of seventh sternite convex near middle. Posterior lobe of eighth tergite not prominent.

This species is closer to Diarthrotarsus malaisei Wygodzinsky and annulosus (Stal) than to the other two known species of the genus. It can be separated from the first by the coloration, the shape of the posterior lobes of the eighth tergite, and the shape of the posterior margin of the pronotum. It can be separated from annulosus by the coloration, the absence of tubercles behind the ocelli, the smoother femora, and the shape of the genitalia.

Holotype: Female, USNM 61730, collected on the northern slopes of Mount Marahuaca, Territorio Amazonas, Venezuela, May 1-25, 1950 . 


\section{Sirthenea venezolana, new species}

Figure 79, $d-f$

Male: Over-all length $11.1 \mathrm{~mm}$. Head, thorax, scutellum, and abdomen black. Ocelli shiny, yellowish. Hemelytra with corium blackish brown with a central large, suboval, stramineous spot; membrane blackish brown, veins black. First, second, and third antennal segments fuscous; fourth stramineous. Rostrum blackish brown, with a very narrow yellowish area at joint of second and third segments. Anterior coxa yellowish, translucent, with black base; trochanter blackish; femur on the inside yellowish, on the outside with three equidistant, longitudinal, wide blackish stripes; tibia dark brown, lighter on the inside; tarsi dark brown. Midcoxa and hind coxa yellowish; trochanters with blackish apices; femur with base and a very small area at apex yellowish, remaining portion blackish; tibia with basal half lighter than apical half which is brownish; tarsi dark brown. Connexivium, dorsally and ventrally, with first segment black, from second to sixth, half and half yellowish and black.

Head as in figure $79, d, f$. Smooth; covered with long pilosity, except above behind eyes and below in front of eyes. Head shorter than thorax. Eyes concave behind, from sides reaching upper and lower margins of head; width of eyes above subequal to interocular space. Preocular region three times as long as postocular; less than one-half total length of head. Distinct postocular transverse impression. Interocellar space broader than diameter of an ocellus. Antenna inserted closer to eyes than to base of rostrum; not reaching to half of body. First segment thickened, slightly curved, narrower at base; second segment thinner; third and fourth slender; all covered with hairs. Proportions of segments $21: 43: 36: 40$. Segments of rostrum relatively slender; proportions of segments 18:37:25.

Pronotum as in figure $79, f$. Anterior lobe $2 \frac{1}{2}$ times as long as posterior; smooth except near anterior margin; with long hairs. Posterior lobe smooth; with deep longitudinal depressions near lateral margins; rounded sinuate in middle. Scutellum large, triangular, with $\mathrm{Y}$-shaped elevation at tip. Wings with sparse long decumbent hairs on corium. Legs covered with long decumbent spinelike hairs and with longer erect bristles among them. Anterior coxa two-thirds as long as femur; trochanter large, triangular; femur swollen, widest before middle, with very long vertical hairs on ventral margin; tibia short, wider at apex, with a spatulate calcar. Midlegs and hind legs with large coxae, prominent trochanters, and slender femora and tibiae, tarsi with two long claws. Forelegs and midlegs subequal in length, short; hind legs long, with tibia and tarsi together as long as forelegs. Upper margins of abdomen straight, below carinate along median line. Body hairy. 
Process of apex of genitalia not hidden by claspers when in repose. Claspers as in figure $79, e$, with upper hind margin roundly produced, not forming a spine; laterally compressed and curved.

Female: More robust than male. With smaller eyes and ocelli. Interocular space nearly twice diameter of an eye from above. Pre ocular region twice as long as postocular. Ocelli less prominent, closer to eyes than to each other, interocellar distance over three times diameter of an ocellus. Antenna and beak stouter than in male. Antennal formula 10:20:20:8. Pronotum broader than male; anterior margin deeply sinuate. Anterior lobe nearly three times as long as posterior; from humeral angles very slightly shorter than broad. Coloration, pilosity, and markings as in the male.

This species is close to Sirthenea vittata Distant and S. peruviana Drake and Harris. It can be separated from both by the much smaller size, antennal formula, proportion of preocular margin to total head length, coloration of legs, and shape and size of the claspers.

Holotype: Male, USNM 61732, collected in the small settlement of Samariapo, $45 \mathrm{~km}$. south of Puerto Ayacucbo, capital of Territorio Amazonas, Venezuela, June 12, 1950; allotype, female, same collecting data, in collection of Carl J. Drake; paratype, male, in author's collection.

\section{Salyavata wygodzinskyi, new species}

Figure $80, a-e$

MaLE: Over-all length $15.6 \mathrm{~mm}$. Head fuscous with a rectangular black area including ocelli on vertex. Eyes black with crystal shiny facets. Ocelli shiny. Antennal first segment black with yellowish base and apex; second with narrow yellowish basal ring, dark to half of segment, yellowish to apex and a narrow black apical ring; third and fourth blackish brown. Blackish brown markings of pronotum as in figure $80, a$; central spine of posterior lobe of pronotum fuscous with blackish apex. Scutellum black; apical erect spine brownish with black tip; postscutellum including apical spine black. Rostrum brown. Anterior coxa blackish; trochanter yellowish; femur with reddish yellow anteapical and apical bands. Two yellowish broad bands on all tibiae. Midfemur and hind femur with two preapical, and one very narrow apical? yellowish bands. Front and hind tarsi brownish. Abdominal segments with broad irregular brownish areas near median line and spiracles. Connexivium with bases of spines blackish; portions between spines yellowish brown.

Head from side and above as in figure $80, b, c$; long pilose. Distance between eyes much less than length of eye; ventrally slightly more than diameter of the rostrum as in figure $80, d$. Antenniferous tubercle small, slightly longer than wide at base, without lateral spines. 
Antennal segments $35: 193: 58: 24$; first segment thicker, slightly shorter than length of head, covered with sparse long hairs of nearly the same length as diameter of segment; second segment thinner than first, covered with long pale hairs which become shorter as they approach apex; third segment thinner than second, pilosity similar to third; fourth of same diameter as third, covered with pale hairs. Rostrum broad, segments 26:20:14. Pronotum slightly wider than long; anterior lobe elevated, one-third of pronotum; sculptured. Posterior lobe with posterolateral spines long; central spine almost vertical, wavy. Scutellum broader than long; lateral margins elevated near base, with an almost vertical long spine at apex. Postscutellum small, with a long, slightly decumbent terminal spine. Wings surpassing end of abdomen; venation and markings as in figure 80,a. Femora slightly incrassate near apices, with sparse vertical pilosity. Tibiae, from about the middle to the apex, with shorter, gradually more abundant and more forwardly inclined hairs. Apical spongy fossae well developed in fore tibia, rounded, shorter than diameter of apical portion of same tibia; smaller in midtibia and hind tibia. Prosternum with anterolateral processes as in figure $80, e$. Fore tarsi 2 -segmented; hind tarsi 3-segmented. Abdomen ventrally with a carina up to the fifth segment; sternites transversely corrugated. Second connexivial segment with anterior and posterior processes; others with posterior, long, upward and backwardly directed spines only.

Posterior process of hypopygium long, elongate, tapering, not lanceolate; upcurved and closely attached to body.

This species is closer to Salyavata nigrofasciata Costa Lima, from which it can be separated by the anterolateral process of the prosternum, absence of a transverse dark band in pronotum, very different color pattern of the hemelytra, and the first antennal segment being less than one-fifth the length of the second.

Holotype: Male, USNM 61731, collected on the northern slopes of Mount Marahuaca, Pacaraima Range, Territorio Amazonas, Venezuela, May 1-25, 1950.

\section{Ctenotrachelus pallidopodus, new species}

FiguRE $80, f-h$

Male: Over-all length $10.2 \mathrm{~mm}$. Body infuscated, legs pale. Head with lighter areas behind antennal sockets and eyes. Antenna and beak stramineous. Anterior lobe of pronotum infuscated;posterior lobe with stramineous areas on ridges. Scutellum black. Hemelytra with scattered irregular stramineous spots, more abundant on membrane; inner discal cell with irregular yellowish longitudinal fascia on outer half; outer discal cell with narrow yellowish fascia adjacent to 

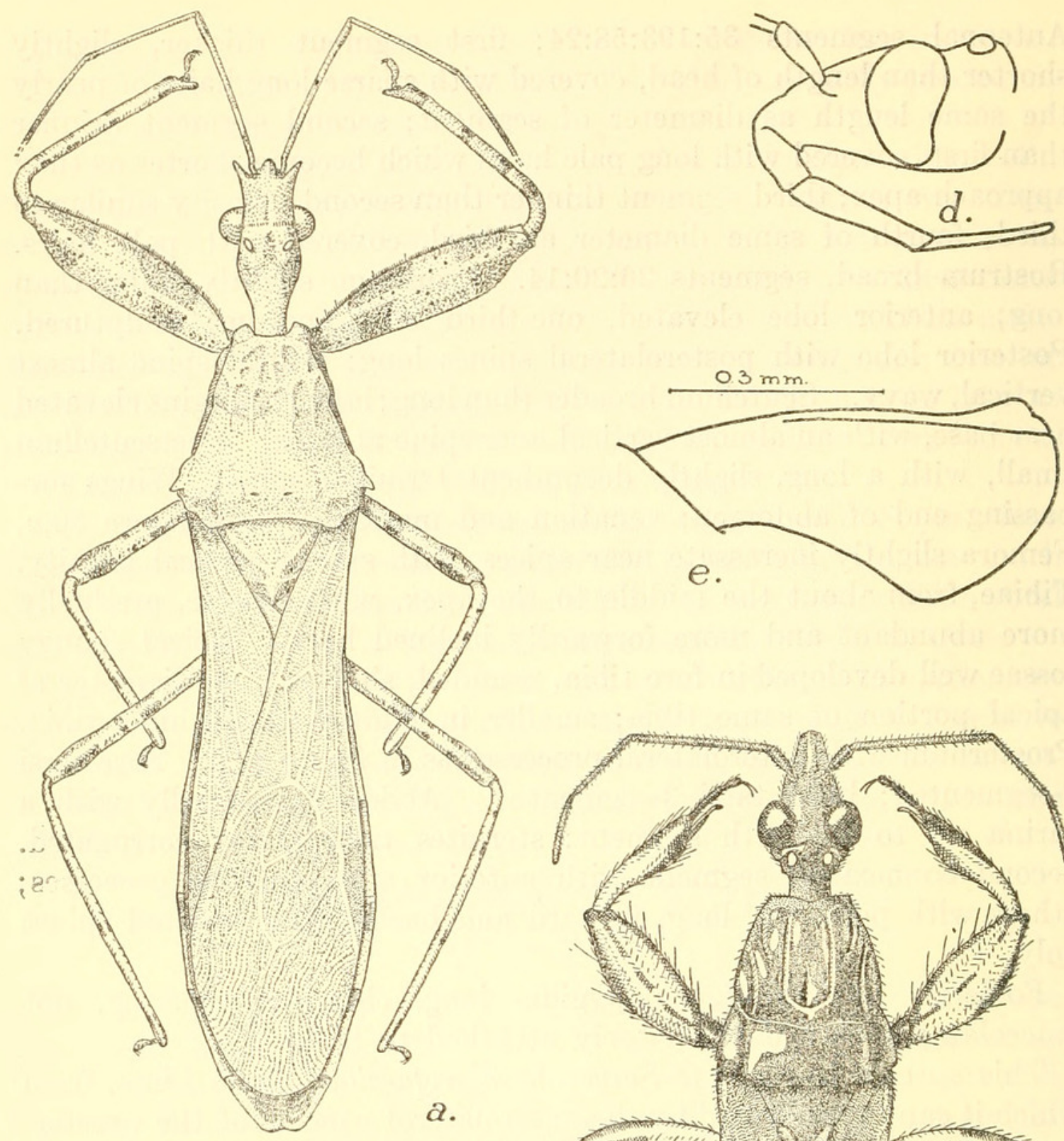

\section{Diarthrotarsus marahuacensis}
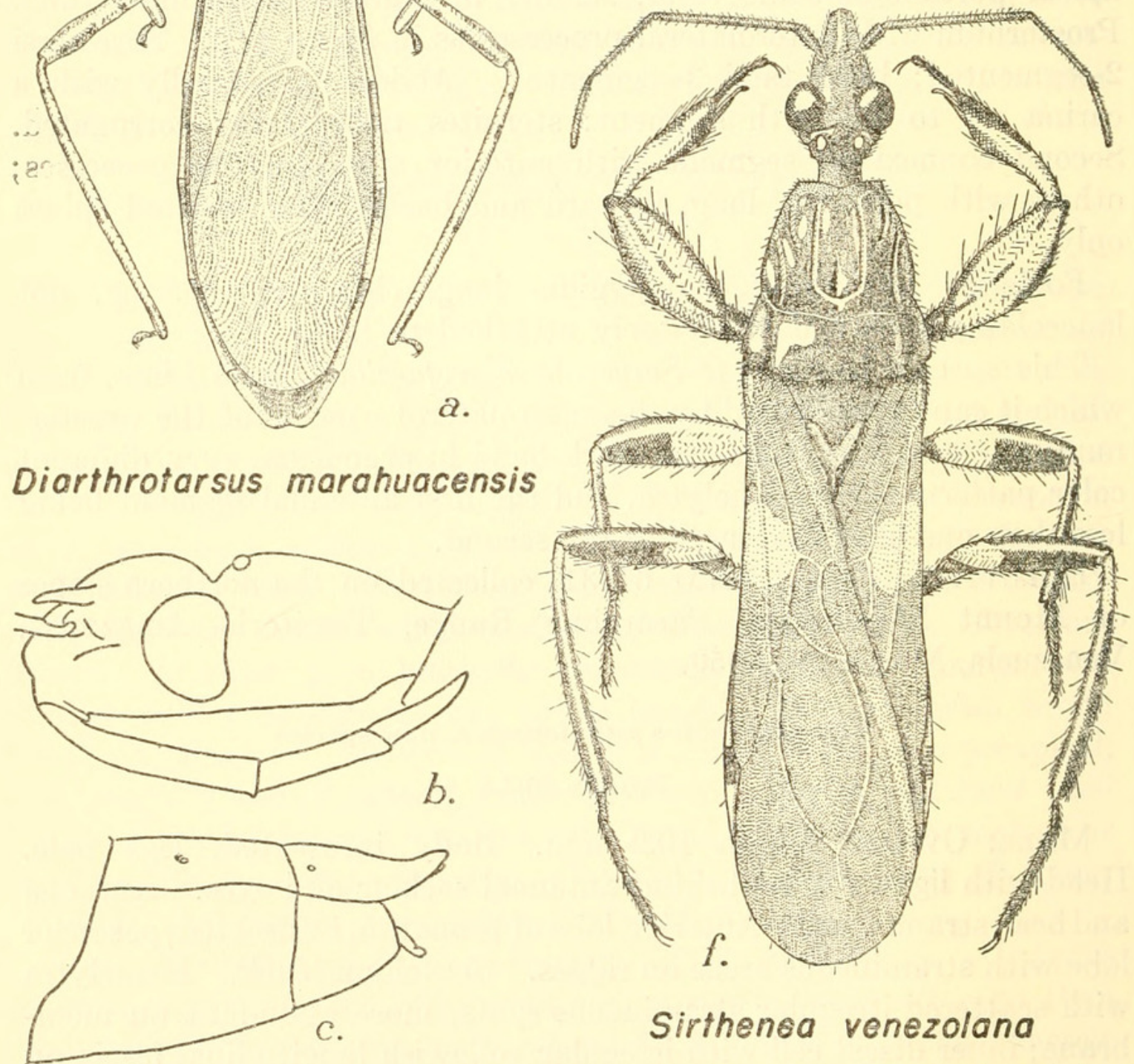

\section{Sirthenea venezolana}

FigURE 79.- $a-c$, Diarthrotarsus marahuacensis, new species: $a$, dorsal view; $b$, lateral view of head; $c$, lateral view of end of abdomen. $d-f$, Sirthenea venezolana, new species: $d$, lateral view of head; $e$, lateroexternal view of clasper; $f$, dorsal aspect of male. 

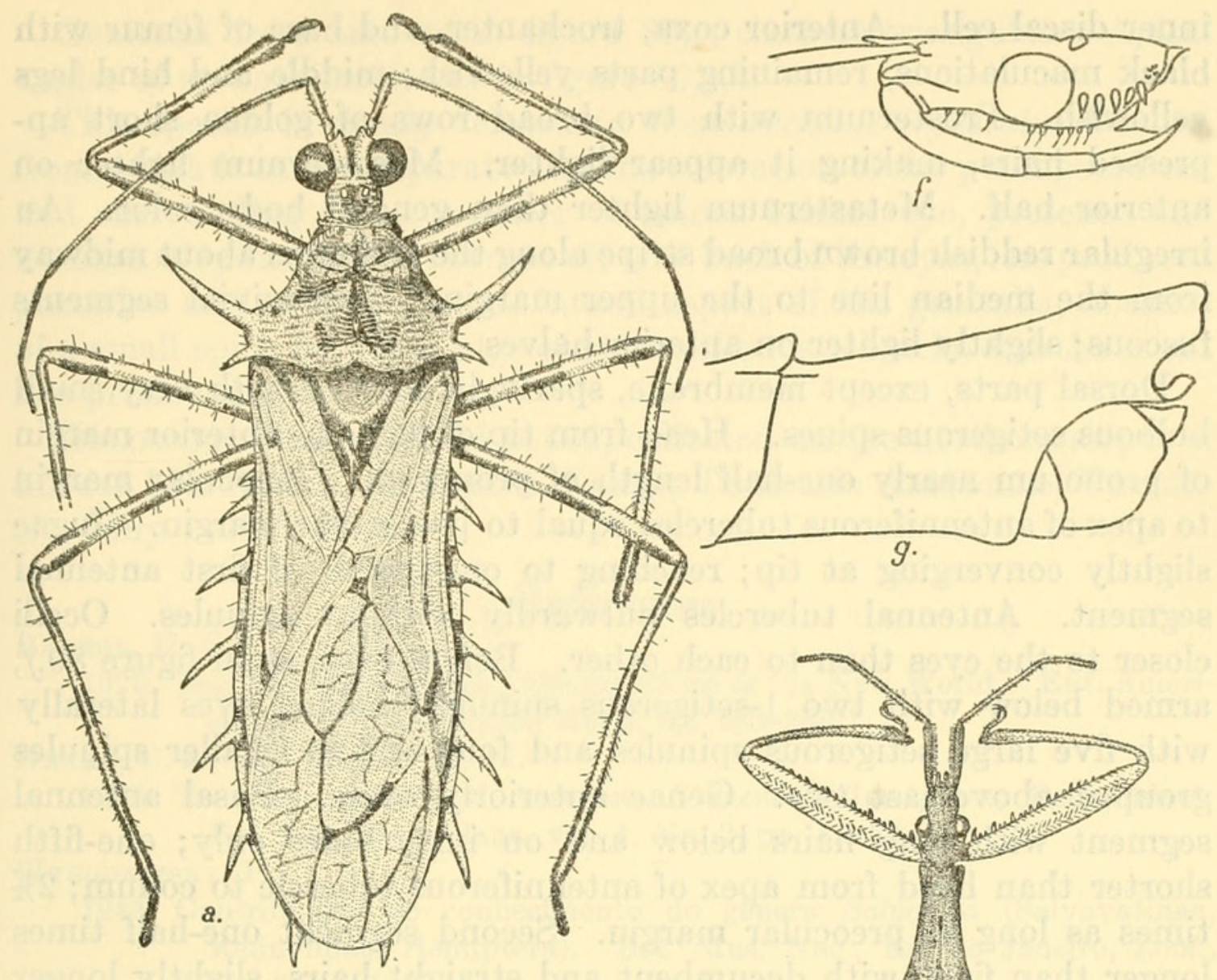

Salyavata wygodzinskyi
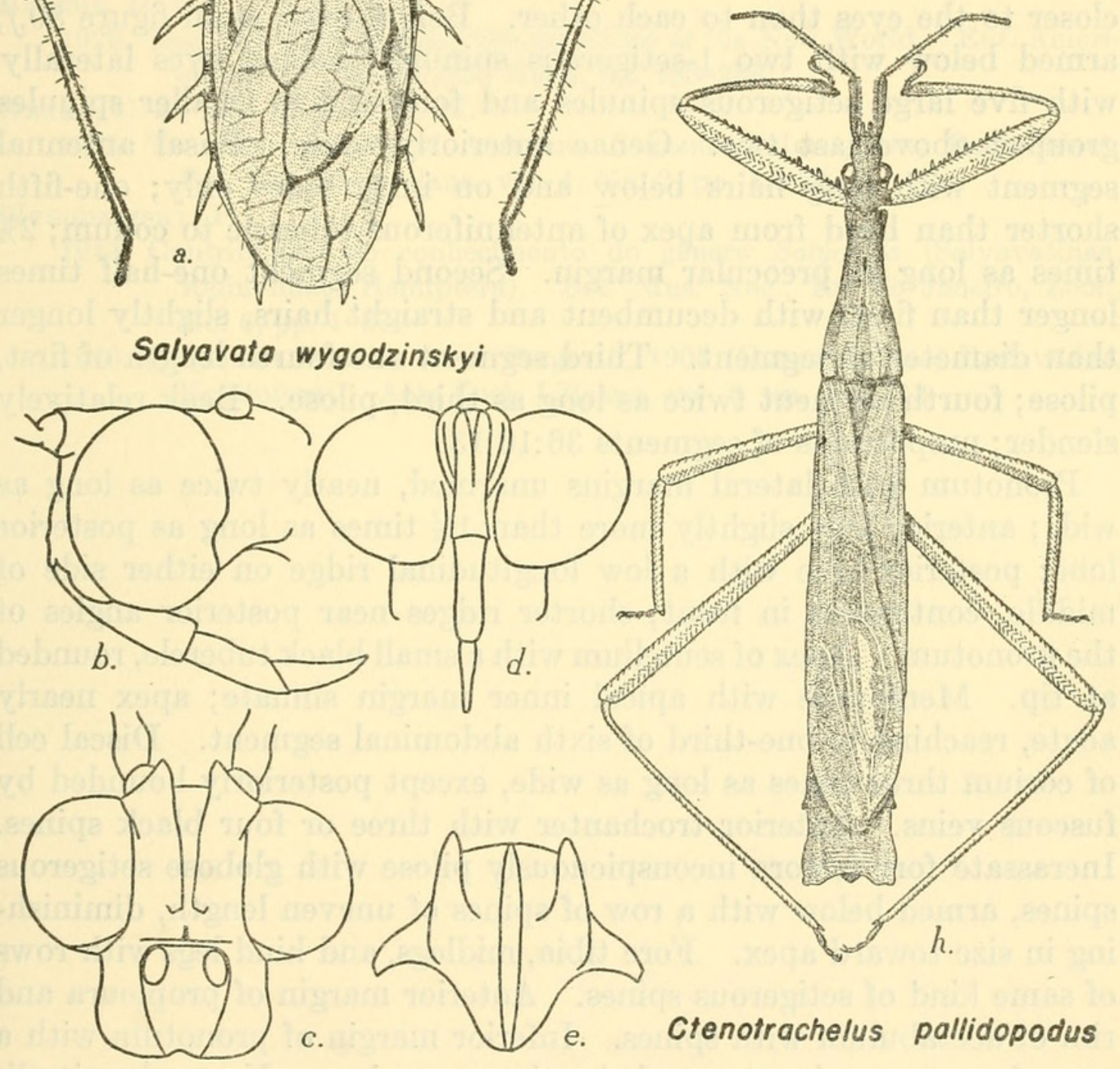

Figure 80.- a-e, Salyavata wygodzinskyi, new species: $a$, dorsal view; $b$, lateral view of head, $c$, dorsal view of head; $d$, ventral view of head; $e$, prosternum. $f-h$, Ctenotrachelus pallidopodus, new species: $f$, lateral view of head; $g$, lateral view of tip of abdomen; $h$, dorsal aspect of male. 
inner discal cell. Anterior coxa, trochanter, and base of femur with black maculations, remaining parts yellowish; middle and hind legs yellowish. Prosternum with two broad rows of golden short appressed hairs, making it appear lighter. Mesosternum lighter on anterior half. Metasternum lighter than general body color. An irregular reddish brown broad stripe along the abdomen about midway from the median line to the upper margin. Connexivial segments fuscous; slightly lighter on anterior halves.

Dorsal parts, except membrane, sparingly covered with very small bulbous setigerous spines. Head from tip of jugae to anterior margin of pronotum nearly one-half length of pronotum. Preocular margin to apex of antenniferous tubercles equal to postocular margin. Jugae slightly converging at tip; reaching to one-fourth of first antennal segment. Antennal tubercles outwardly without spinules. Ocelli closer to the eyes than to each other. Before eyes, as in figure $80, f$, armed below with two 1-setigerous spinules; behind eyes laterally with five large setigerous spinules and four or five smaller spinules grouped above last two. Genae anteriorly acute. Basal antennal segment with long hairs below and on inner sides only; one-fifth shorter than head from apex of antenniferous tubercle to collum; $2 \frac{1}{2}$ times as long as preocular margin. Second segment one-half times longer than first, with decumbent and straight hairs, slightly longer than diameter of segment. Third segment one-fourth length of first, pilose; fourth segment twice as long as third, pilose. Beak relatively slender; proportions of segments $36: 16: 13$.

Pronotum with lateral margins unarmed, nearly twice as long as wide; anterior lobe slightly more than $1 \frac{1}{2}$ times as long as posterior lobe; posterior lobe with a low longitudinal ridge on either side of middle, contiguous in front; shorter ridges near posterior angles of the pronotum. Apex of scutellum with a small black tubercle, rounded at tip. Membrane with apical inner margin sinuate; apex nearly acute, reaching to one-third of sixth abdominal segment. Discal cell of corium three times as long as wide, except posteriorly bounded by fuscous veins. Anterior trochanter with three or four black spines. Incrassate fore femora inconspicuously pilose with globose setigerous spines, armed below with a row of spines of uneven length, diminishing in size toward apex. Fore tibia, midlegs, and hind legs with rows of same kind of setigerous spines. Anterior margin of propleura and rim of acetabulum with spines. Inferior margin of pronotum with a row of more prominent rounded setigerous spines. Venter longitudinally ridged to end of third visible segment and carinate to end of sixth. Apical angles of connexivial segments acutely prominent; margins with setigerous spines. 
Genitalia from side as in figure $80, g$, claspers triangular. Apical angles of seventh tergite as in figure $80, g, h$.

This species is closely related to Ctenotrachelus infuscatus Barber, from which it can be separated by the coloration of the pentagonal cell and surrounding veins, number of spines behind eye, presence and number of spines below, in front of, and back of the eyes, less produced posterior angles of the terga, lateral aspect of the genitalia, absence of a small spine on outer edge of antenniferous tubercle, and the much less produced gena.

Holotype: Male USNM 61802, collected on the northern slopes of Mount Marahuaca, Pacaraima Range, Territorio Amazonas, Venezuela, May 1-25, 1950.

BARBer, H. G.

\section{References}

1929. Essay on the subfamily Stenopodinae of the New World. Ent. Americana, vol. 10, new ser., No. 4, pp. 193-238.

Drake, C. J., and Harris, H. M.

1945. Two new species of American Sirthenea (Hemiptera; Reduviidae).

Bol. Ent. Venezolana, vol. 4, No. 2, pp. 55-58.

Wygodzinsky, P.

1943. Contribuïção ao conhecimento do gênero Salyavata (Salyavatinae, Reduviidae, Hemiptera). Bol. Mus. Nac., Rio de Janeiro, Zool., No. 6, pp. 1-27.

1948. El género Diarthrotarsus Bergroth, 1905 (Harpactorinae, Reduviidae, Hemiptera). Acta Zool. Lilloana, vol. 6, pp. 201-213. 


\section{$2 \mathrm{BHL}$ Biodiversity Heritage Library}

1955. "Four new Venezuelan Reduviid bugs." Proceedings of the United States National Museum 104(3340), 105-113. https://doi.org/10.5479/si.00963801.104-3340.105.

View This Item Online: https://www.biodiversitylibrary.org/item/52773

DOI: https://doi.org/10.5479/si.00963801.104-3340.105

Permalink: https://www.biodiversitylibrary.org/partpdf/51037.

\section{Holding Institution}

Smithsonian Libraries

\section{Sponsored by}

Smithsonian

\section{Copyright \& Reuse}

Copyright Status: Public domain. The BHL considers that this work is no longer under copyright protection.

This document was created from content at the Biodiversity Heritage Library, the world's largest open access digital library for biodiversity literature and archives. Visit BHL at https://www.biodiversitylibrary.org. 